Pavol Štubňa

Comenius University in Bratislava

pavol.stubna@uniba.sk

ORCID: 0000-0002-6871-059X
Data przesłania tekstu do redakcji: 02.09.2020

Data przyjęcia tekstu do druku: 05.11.2020

\title{
Sociálne a vzdelávacie funkcie (literárnych) naratív
}

Abstract: Štubňa Pavol, Sociálne a vzdelávacie funkcie (literárnych) naratív (Social and Educational Functions of [Literary] Narratives). "Poznańskie Studia Slawistyczne" 19. Poznań 2020. Publishing House of the Poznań Society for the Advancement of the Arts and Sciences, Adam Mickiewicz University, pp. 363-377. ISSN 2084-3011.

The study deals with social and educational functions of (literary) narratives - both oral and written - in everyday life of a socially grounded individual. Narratives (or stories told or read) play an essential role in building and strengthening social bonds within a community (by spending time together, informing its members of preferred social values and behaviour patterns, etc.) The author sustains that narratives circulating within a particular community (or ethnic group, nation) should be viewed and analyzed from the perspective of cultural anthropology.

As an educational tool, stories are utilized not only in families and schools, but also in penitentiary and correctional institutions or in public reading courses.

The author also pays attention to particular structural components of "captivating" narratives (such as novelty, surprise, cognitive and/or emotional relevance to the reader, etc.) and so-called narrative universals - themes, types of characters, plots and settings that are common to all cultures worldwide (such as romantic love, human desires and needs, sacrifice, etc.).

KEYWORDS: narrative; narrative universals; social function; educational function

\section{Úvod}

Narácia tvorí vel'kú čast' l'udskej komunikácie a kultúry. Každodenne sa presviedčame o tom, že medzil'udská komunikačná interakcia je charakterizovaná naratívnym štýlom - l’udia sa navzájom neustále informujú o svojich stavoch a udalostiach (pracovných, súkromných, spoločenských, ekonomických, iných) uplynulých dní. Podl'a nedávnych vedeckých výskumov, realizovaných prevažne v jazykovo rozvinutých kultúrach, sa priemerný počet slov, ktoré jedinec v priebehu dňa použije, pohybuje okolo 15000 (Mehl, Vazire, Ramírez-Esparza, Slatcher, Pennbaker, 2007). Ako 
dve hlavné zložky spontánneho jazykového vyjadrovania boli identifikované: výmena názorov (diskusia) a narácia (prevažne vo forme informácií o minulých udalostiach) (Dessalles, 2007). V tejto súvislosti S. Egginsová a D. Sladeová $(1997,265)$ vo výskume zameranom na vol'nočasové konverzačné témy ( $v$ priebehu stretnutí trvajúcich približne tri hodiny) zistili nasledovnú tematickú distribúciu: rozprávanie vo forme príbehu (s uplatnením časovej postupnosti jednotlivých udalostí) predstavovalo 43,4 \% času, pozorovania a komentáre $19,75 \%$, názory $16,8 \%$, klebety $13,8 \%$ a rozprávanie vtipov $6,3 \%$ spoločne stráveného času.

Zámerom tejto štúdie bude súčasne poukázat' na kultúrnoantropologický, respektíve evolučný charakter fenoménu (literárnych) naratív a následné možnosti využitia na výchovné a vzdelávacie účely.

\section{Definícia pojmov - narácia, príbeh, naratívum}

Z metodologického hl'adiska budeme pri narábaní s pojmami - narácia, príbeh, narativum - vychádzat' z ich významov tak, ako ich definovali predstavitelia naratívnej psychológie (Brewer, Sarbin), pretože sa domnievame, že naratíva ako kultúrnoantropologický fenomén naplńajú svojím obsahom primárne psychologické potreby (napr. kolektívna identita, potreba bezpečia, ochrany a pomoci, potreba autonómie, uznania, poriadku a pod.) členov daného kultúrneho spoločenstva. Pre porovnanie súčasne uvádzame aj definície zástupcov tzv. klasickej (štrukturalistickej) naratológie (Todorov, Prince).

Podl'a Sarbina je narácia (angl. narrative) synonymom príbehu (angl. story). „Príbeh je symbolizovaný opis konania l'udí, ktorý má časovú dimenziu. Príbeh má začiatok, stred a zakončenie. Je stmelený rozpoznatel'nými schémami udalostí (angl. plots)“ (Sarbin, 1986, 10). Hlavný význam v štruktúre zápletky majú príjemné alebo nepríjemné situácie zo života a ich postoje $\mathrm{k}$ nim.

Naopak, Brewer (1985) dôsledne rozlišuje medzi naráciou (rozprávaním, opisom) a príbehom. Naráciou môže byt' podl'a neho akákol'vek časová následnost' udalostí. Príbeh však musí mat' úvodnú zápletku a jej konečné rozuzlenie (výsledok, ciel'). Musí tiež obsahovat' nejakú kritickú alebo inak významnú udalost' a jej vyriešenie. Akákol'vek súslednost' 
udalostí bez týchto troch prvkov, nemôže byt' podl'a Brewera považovaná za príbeh, iba za naráciu ${ }^{1}$.

Termínom narativum, resp. naratív sa zasa označuje súhrn rozprávaných udalostí (stavebných jednotiek príbehu zachytávajúcich zmenu nejakého stavu), ale tiež súhrn prostriedkov slúžiacich na referovanie o týchto udalostiach. Vyjadrené slovami zakladatel'a tradičnej naratológie Todorova:

Na najvšeobecnejšej úrovni má literárne dielo dva aspekty - je súčasne príbehom aj diskurzom. Príbehom v tom zmysle, že evokuje určitú skutočnost', udalosti, ktoré sa údajne stali a postavy, ktoré z tohto dôvodu splývajú s postavami zo skutočného sveta. [...] avšak takýto výtvor je súčasne aj diskurzom, pretože existuje rozprávač, ktorý príbeh rozpráva, a oproti nemu stojí čitatel', ktorý ho vníma. Na tejto úrovni nejde teda iba o referovanie o udalostiach, ale tiež o spôsob, ktorým nás s nimi rozprávač oboznamuje (Todorov, 2002, 144).

Pre porovnanie, Prince $(1987,58)$ definuje naratív ako ,zobrazenie (proces aj výsledok, objekt aj naratívny akt, štruktúra aj jej vytváranie) jednej či viacerých skutočných alebo fiktívnych udalostí sprostredkovaných jedným či viacerými rozprávačmi jednému či viacerým adresátom“ (Bílek, 2003, 127).

\section{Naratívne univerzálie}

Domnievame sa, že l'udská potreba rozprávat' a počúvat' príbehy je komplexný viacúrovňový fenomén, ktorý je potrebné vnímat' v kontexte celej evolúcie l'udského druhu. Túto teóriu mienime podporit' zisteniami neurovedcov, psychológov a antropológov, ktorí skúmali tzv. naratívne univerzálie - témy, typy postáv, zápletky deja a prostredie príbehov, ktoré sú spoločné všetkým kultúram v celosvetovom meradle. V roku 2006 objavil Jonathan Gottschall relevantnú zhodu v opisoch romantickej lásky v l'udových príbehoch pochádzajúcich z rozličných kultúr a z rozličných historických období (Hsu, 2008, 50). Predstava romantickej lásky nebola dovtedy považovaná za kultúrnu univerzáliu, pretože v mnohých kultúrach

${ }^{1} \mathrm{~V}$ prípade literárnych komunikátov je narácia ,zvláštnou formou sprostredkovanej intersubjektivity, ked' text - médium - umožňuje čitatel'om vstupovat' do početných vzt'ahov s fiktívnymi postavami a prostredníctvom nich aj do vzt'ahu s autorom"(Gallese, Wojciehowski, 2010, 27). 
je sobáš výsledkom ekonomických, sociálnych či inak spoločensky motivovaných záujmov. Gottschallovova publikácia Literature, Science, and New Humanities (Literatúra, veda a nové humanitné vedy), vydaná v roku 2008, priniesla zasa zaujímavé zistenia ohl'adom rodových rolí. Jeho tím analyzoval obsah devät'desiatich zbierok l'udových rozprávok, pričom každá z nich pozostávala približne z 50 až 100 príbehov pochádzajúcich z rozličných typov kultúr - od pôvodných kmeňov žijúcich prírodným spôsobom (zberači, lovci) až po rozvinuté industriálne kultúry. Zistili, že prevažná väčšina rodových opisov zdôrazňovala mužskú silu a ženskú krásu. Gottschall dokonca konštatoval, že jeho tím neobjavil ani jedinú kultúru, ktorá by nejako výraznejšie upozorňovala na mužskú krásu. Toto zistenie je o to zaujímavejšie, že v celkových počtoch obsahovali skúmané príbehy trojnásobok mužských postáv ako ženských. Na druhej strane, v analyzovaných príbehoch sa vyskytlo šest'krát viac odkazov na ženskú než na mužskú krásu (Gottschall, 2008, 100). Z vývinového antropologického hl'adiska by následne mohli tieto údaje podporovat' Darwinovu reprodukčnú teóriu, podl'a ktorej sú spoločnost’ou najviac oceňovanými ženskými kvalitami krása a mladost'. U mužov sú nimi zasa fyzická sila a spoločenský úspech, vd’aka ktorým dokážu existenciálne zabezpečit' svoj rod a potomkov. Ako vidíme, nielen samotné témy príbehov, ale aj viaceré fyziologické charakteristiky protagonistov možno vnímat' ako narativne univerzálie, pretože v mnohom odrážajú spoločné biologické danosti l'udského druhu.

Inou zistenou tematickou univerzáliou boli l'udské túžby a potreby. Profesor porovnávacej literatúry z Univerzity v Connecticute P. C. Hogan zistil, že viac ako dve tretiny najvýznamnejších príbehov v kultúrnych tradíciách celého sveta sú v podstate variáciami na tri rozprávačské motívy, vzorce či prototypy, ako ich sám nazval. Prvým z nich sú útrapy (romantickej) lásky, druhým zápas o moc a tretí je spojený s obetou v zmysle „vyššieho“ sociálneho záujmu (napr. záchrana spoločenstva pred hladomorom či iným druhom záhuby) (Hogan, 2003)². Opät' ide poväčšine o sociálno-evolučné témy

${ }^{2}$ Domnievame sa, že za naratívnu univerzáliu (zobrazenú ako celok alebo vo fragmetarizovanej podobe) možno považovat’ aj národný, resp. etnický „obraz“ daného spoločenstva zahŕňajúci jeho psychologické, sociálne či iné charakteristiky. Procesu vzniku a kultivácie takéhoto „obrazu“ národnej identity sa v monografii Odvrávajúce obrazy venuje Fülöpová (2014). Vznik slovenskej národnej identity zasa objasňuje pomocou analýzy Sádkovičovho Detvana v štúdii Archetypálny hrdina v idylickom svete (2020). 
súvisiace s prežitím l'udského druhu, konkrétne s vytvorením, udržaním, resp. zmenou spoločenskej hierarchie (štruktúry) a s obetou jednotlivca v prospech (na záchranu) celku - komunity, etnika či národa.

Náš antropologický predpoklad týkajúci priamej súvislosti medzi naratívami (roz)šírenými v rámci určitého kultúrneho spoločenstva a jeho sociálnym vývojom v čase podporuje aj Chaffeho výskum zameraný na zist'ovanie rozdielov $v$ modulácii (fyzikálne) identického vstupu (angl. discrepant modelling of physically identical input) (Chaffe, 1990, 82). Účastníci tohto experimentu prejavovali totiž tendenciu upravovat' prenášaný informačný obsah tak, aby zodpovedal ich predchádzajúcim poznatkom o podobných udalostiach a ich životným skúsenostiam, čím implicitne zahrnuli do neho aj spoločenské udalosti a skúsenosti celého spoločenstva, ktorého sú integrálnou súčast'ou. O niekol'ko desat'ročí neskôr Bangerter (2000) zistil, že modifikácie v prenose takýchto informácií závisia aj od stereotypov (myslenia, cítenia a pod.) charakteristických pre jednotlivé pohlavia. Tieto sa však okrem biologického rodu z vel'kej časti zhodujú $\mathrm{s}$ tzv. rodovými rolami³ ${ }^{3}$ ktoré sú výsledkom pôsobenia konkrétnych kultúrno(antropologických) faktorov ovplyvňujúcich život každého spoločenstva individuálnym spôsobom. Lyons a Kashima obohatili predchádzajúce výskumy o poznatok, že informácie založené na stereotypoch sú prenášané omnoho presnejšie ako informácie, ktoré sa na stereotypoch (vrátane tých rodových) nezakladajú, a teda je potrebné vynaložit' na ich zapamätanie osobitú námahu, pretože jedinec nemôže opakovane použit žiadnu z už existujúcich, ním osvojených a integrovaných schém myslenia. My pripomíname, že vždy ide o kultúrne a sociálne podmienené schémy uvažovania, ktoré vznikli a tradujú sa vždy v rámci konkrétneho spoločenstva ${ }^{4}$. Napokon, Mesoudi a jeho spolupracovníci vo výskume realizovanom v roku 2008 zistili, že správnost' prenášaných informačných obsahov súvisí s tým,

${ }^{3}$ Rodové role chápeme v zmysle kultúrne a sociálne podmienených rozdielov medzi mužmi a ženami, vychádzajúc z anglického termínu gender (rod). Odlišujú sa v rámci každého spoločenstva (etnika, národa), a súčasne neustále variujú - menia sa v čase a priestore. Primárne ide o rozlišovanie sociokultúrnych funkcii maskulinity a feminity. Pozri aj Cingerová a Dulebová (2019, 78-79).

${ }^{4}$ Uvedomujeme si, že špecifický spôsob myslenia je zakaždým podmienený používaním konkrétneho jazykového systému ako komunikačného kódu, no daná problematika nie je predmetom tejto štúdie. 
či ide o sociálne alebo nesociálne skutočnosti, pričom jednoznačnú prevahu predstavovali prvky súvisiace s každodennou sociálnou interakciou (Mesoudi, Whiten, 2008, 3509), čím potvrdili opätovne spätost' sociálnej komunikácie, a teda aj sociálnych komunikátov (napr. naratív) s každodenným životom (kultúrnoantropologickým vývojom) komunity.

\section{Sociálne funkcie naratívnych komunikátov}

Podl'a kultúrnych antropológov pretrvalo rozprávanie príbehov v l'udskej kultúre tak dlho preto, že ide o prostriedok, ktorý pomáha upevňovat' sociálnu súdržnost' medzi skupinami a tiež slúži ako cenný nástroj odovzdávania poznatkov a vedomostí medzi generáciami ${ }^{5}$.

Mar a Oatley (2008) zastávajú názor, že reálne aj fiktívne narácie umožňujú sprostredkovat' predovšetkým sociálne poznatky (poznanie), nie poznatky všeobecného charakteru. Podl'a nich slúžia (aj) fiktívne príbehy ako „tréningová aktivita“, v priebehu ktorej sa jedinec snaží porozumiet’ názorom a pocitom iných l'udí, a ktorá mu umožňuje objavovat' nové riešenia na opakujúce sa situácie (problémy) každodenného bytia (Cook, 1997; Keen, 2006; Mar et al., 2006; Zunshine, 2006) ${ }^{6}$. Mar a Oatley tak považujú fikciu za „užitočnú simuláciu konania jednotlivcov v (skutočnom) sociálnom svete“ (2008, 173), pretože fiktívne príbehy majú rovnaké základné charakteristiky ako reálne príbehy a vyvolávajú aj podobné kognitívne odpovede. Takže z istého uhla pohl'adu môžu byt' fiktívne príbehy vnímané ako nástroje na precvičovanie a zlepšovanie l'udskej schopnosti interakcie v komplexnom sociálnom prostredí (Boyd, 2009). Oatleyho a Marov výskum z roku 2006 potvrdil taktiež priamu úmeru medzi čítaním beletrie a sociálnymi zručnost’ami, ako aj s výsledkami testov na zist’ovanie (miery) empatie (Oatley, Mar, 2006).

Podl'a Dessallesových (2008) zistení sú fiktívne príbehy odrazom nefiktívnych správ o udalostiach, pokial' ide o ich štruktúru aj recepciu.

${ }^{5}$ Už v roku 1997 antropológ a evolučný biológ Robin Dunbar (University of Liverpool) zistil, že sociálne témy predstavovali až $65 \%$ času v rámci interpersonálnej komunikácie (konverzácie) na verejných miestach, bez ohl'adu na vek a pohlavie pozorovaných subjektov (Dessalles, 2008, 91).

${ }^{6}$ Obzvlášt' evidentná je táto skutočnost' v prípade rozprávok pre deti, prostredníctvom ktorých dospelí ukazujú det’om, ktoré sociálne normy a formy správania sú $\mathrm{v}$ danom spoločenstve považované za žiaduce a ktoré za neprijatel'né. 
Zistilo sa, že z kognitívneho hl'adiska reagujú recipienti na fiktívne príbehy obdobne ako na skutočné životné udalosti. Samozrejme, každá beletristické dielo je pri recepcii vnímané, spracovávané a interpretované na základe osobných skúseností, znalostí, zážitkov a spomienok (Halasz, 1991). Viacero teoretikov literatúry dnes (literárnu) fikciu vníma v zmysle 'modelu (každodennej) reality' - ako aproximáciu implikujúcu nevyhnutnú redukciu (Oatley, Mar, 2005, 182).

Tvrdenie, že fiktívne príbehy môžu slúžit' ako tréningová aktivita pre reálne životné situácie sociálneho charakteru, podporujú aj výsledky neuropsychologických výskumov (magnetic resonance imaging), podl'a ktorých l'udský mozog pri pohl'ade na skutočných l'udí prejavuje podobnú nervovú aktivitu ako pri pohl'ade na animované postavičky. V oboch prípadoch, aj ked' v odlišnej miere, bolo vedecky zistené zapojenie ohraničenej siete mozgových oblastí - mediálnej prefrontálnej a oblasti temporo-parietálneho spoja. Práve rozdielnost' v intenzite mozgovej aktivity sa považuje za rozdiel medzi realitou a fantáziou.

Aj ked' človek vie, že fiktívne príbehy nerozprávajú o udalostiach, ktoré sa skutočne stali, má tendenciu reagovat' na ne, ako by boli skutočné (Walton, 1978; Skulsky, 1980; Gerrig, 1989), pretože za hranicami toho, čo je vo svete možné, mu umožňujú aplikovat' poznatky (poznanie) z nich získané na široké spektrum (potenciálnych) reálnych životných situácií.

Behaviorálne orientovaní psychológovia upozorňujú v tejto súvislosti na možnosti využitia l'udského sklonu k obl'ube príbehov v programoch sociálneho učenia a prevýchovy. V nich sú „klientom“ sprostredkovávané žiaduce informácie a vzory správania pomocou skutočných životných príbehov „obyčajných“ l'udí, príp. prostredníctvom „tematických spovedí“ verejne známych osôb (napr. na tému alkoholovej či drogovej závislosti, porúch prijímania potravy a pod.).

\section{Príbeh ako výchovný a vzdelávací prostriedok}

Náš predpoklad o (kultúrno)antropologickej podmienenosti naratív ${ }^{7}$ možno vztiahnut' aj na teóriu sociálnej psychologičky Plichtovej (2002), podl'a ktorej každý osobný príbeh v sebe obsahuje akýsi pravzor príbehu

${ }^{7}$ Prirodzene aj literárnych naratív - a to nielen z pohl'adu obsahu aj formy. 
danej spoločnosti, a tým odráža spoločne zdiel'ané významy, hodnoty a normy daného spoločenstva ${ }^{8}$. Narativita teda $v$ sebe obsahuje odraz reality aj jej interpretáciu. Popritom sa ,literatúra ako forma poznania a interpretácie sveta vyznačuje špecifickou spoluúčast'ou a identifikáciou čitatel’a s tým, čo práve popisuje“ (Mesárová, 2014, 42).

V súvislosti s výchovou a vzdelávaním jedinca, ktorý je vždy súčast'ou konkrétnej komunity v rámci danej kultúry, plnia príbehy niekol'ko významných funkcií (Štubňa, 2017, 81-82). Príbehy sú istou formou mentálnej hry, ktorá pomáha rozvíjat' (detskú) predstavivost', abstraktné myslenie, sústredenie, pamät' aj rečové schopnosti jedinca. Tento aspekt je významný najmä z pohl'adu rozvoja kognitívnych funkcií.

Počas rozprávania príbehu môže dospelý poskytnút' diet'at'u nový uhol pohl'adu na opisovanú situáciu, čím ho učí rozmýšl'at' (uvažovat') objektívne, kriticky a inovatívne. Upozorňujeme však, že z pohl'adu arteterapie je dôležité prihliadat' na tie aspekty príbehu, na ktoré sa diet’a aktuálne zameria, aj ked’ sú v rozpore s pôvodným zámerom a očakávaním dospelého, ktorý sa naň snaží (konkrétnym - subjektívne zvoleným spôsobom) pôsobit', pretože majú potenciál indikovat' významný fyziologický, emocionálny či kognitívny deficit, ktorým diet’a dlhšiu dobu trpí, a ktorý je potrebné čím skôr detegovat' a vyrovnat'.

Výberom konkrétnych príbehov dokáže rodič či pedagóg ovplyvňovat' vývoj morálneho vedomia diet'at'a. Na príklade konkrétnych postáv a ich osudov sa diet'a uči mentalizovat', čiže odhadovat' psychický stav, emočné rozpoloženie a pohnútky konania iných osôb. Pomocou príbehov sa diet'a zoznamuje s princípom príciny a následku.

Pre deti vychovávané v režime (s priestorovými či inými obmedzeniami, napr. deti v detských domovoch, v nápravných zariadeniach, deti úzkostlivých rodičov a pod.) sú príbehy formou sprostredkovaného (dobrodružného, umeleckého a i.) zážitku, surogátnou formou získavania životných skúseností (napr. návod ako riešit’ problémy v medzil'udskej komunikácii, ako sa vyrovnat' s fyziologickými a psychickými zmenami sprevádzajúcimi dospievanie, osvojovanie si rozličných sociálnych zručností a pod.)

${ }^{8}$ Mesárová $(2015,52)$ upozorňuje, že túto oblast' možno preskúmat' i použitím mýtov, ktoré v modernej beletrii ponúkajú hlavne príbehy patriace do prúdu tzv. magického realizmu. 
Na základe vzorových modelov (správania, postoja a iných) prezentovaných $\mathrm{v}$ príbehoch (napr. $\mathrm{v}$ rozprávkach) sa posilňuje dôvera diet'at'a vo vlastné schopnosti. Jedinec zist'uje, že konkrétne životné okolnosti nie sú nemenné a existujú možnosti na ich zmenu. Napriek (najmä emocionálne) výrazne deficitnej životnej situácii (napr. deti v detských domovoch, ktoré sa v dôsledku straty prirodzených rodičovských väzieb neraz cítia osamelé, ublížené, slabé, bez opory a pomoci, nehodné lásky a pod.) tak môžu určité príbehy poskytnút' det'om cennú perspektívu pre budúci život'.

Spoločné čítanie (doma, v škole) buduje u detí pozitívny vzt’ah ku knihám ako konštruktívnej, tvorivej a poučnej alternatíve trávenia vol'ného času. Navyše, spoločné čítanie príbehov umožňuje rozprávačovi (napr. rodičovi) prispôsobit' ich dej, postavy a posolstvo vekovej kategórii poslucháčov, t. j. upravit' didaktický zámer príbehu tak, aby vyhovoval aktuálnym výchovným požiadavkám. Pri narábaní s príbehom je potrebné osobitne zvážit' tri faktory: jeho výber, spôsob podania (prerozprávania) a záverečnú analýzu posolstva, ktoré obsahuje (Štubňa, 2017, 81-82).

Tvorivost' diet'at'a môže rodič (resp. pedagóg) rozvíjat' aj pomocou požiadavky zmenit' (upravit') zakončenie príbehu, príp. niektorú jeho čast'. Niektorí autori (napr. Bátoryová, Kusý, 2012; Tabačková, Kusý, 2014; Kusý, 2015, 2018 a iní) dokonca odporúčajú kombinovat' príbehy hravou formou s hudbou a pohybom, čím sa môže zefektívnit' celkové rozvíjanie tvorivosti v detskom veku.

Rozprávanie príbehov - verbálna aj neverbálna komunikácia s rozprávačom počas tejto aktivity - umožňuje det'om identifikovat' a kategorizovat' mentálne aj emocionálne rozprávača ako osobu, ktorá schval'uje, resp. odsudzuje konanie určitej postavy v príbehu (rozprávač tým diet’at’u poskytuje informáciu o svojich morálnych presvedčeniach a hodnotách). $\mathrm{V}$ prípade nedirektívneho výchovného pôsobenia tak môže byt' príbeh účinným výchovným prostriedkom, ktorý umožní diet'at'u nepriamym spôsobom osvojit' si žiaduce normy správania ${ }^{10}$.

${ }^{9}$ Napr. príbeh o Harrym Potterovi - chlapcovi vychovávanom náhradnými rodičmi v citovo chladnom prostredí, kde musí znášat' nespravodlivé zaobchádzanie zo strany svojich príbuzných - môže diet'at’u ukázat', že napriek „,nepriazni osudu“ môže z neho vyrást' obdivovaný „hrdina“, a že rodinu netvoria len pokrvné putá, ale aj vzt'ahy s hodnotovo podobne orientovanými l'ud'mi.

${ }^{10} \mathrm{~V}$ kontexte českého a slovenského základného školstva a predškolských zariadení sa problematikou využitia literárnych diel vo výchovnom a vzdelávacom procese 
Diskusia diet'at’a s dospelým o deji príbehu a konaní jednotlivých postáv rozvíja aj argumentačné schopnosti diet'at'a a jeho kritické myslenie. Rovnako platí, že pôsobenie nesprávnym spôsobom - kultúrne, sociálne či nábožensky zaujatým (tendenčným) - dokáže kritické myslenie diet'at'a výrazne deformovat'.

Vo vyššom veku posilňuje (samostatné) čítanie nezávislost' dospievajúceho jedinca - jednak v zmysle schopnosti osamote trávit’ čas (bez prítomnosti iných osôb, od ktorých by mohlo byt' závislé), jednak v zmysle samostatného konania spojeného s cieleným výberom činnosti (čítanie) a jej konkrétneho prejavu (čítanie konkrétneho diela, konkrétneho žánru, podžánru a pod.). Zo skúsenosti vieme, že najmä rodinné prostredie a správanie vzorových postáv - rodičov, resp. vychovávatel'ov je kl’účovým faktorom ovplyvňujúcim prípadné osvojenie si tejto činnosti. Forma trávenia vol'ného času detí súvisí výrazne aj s hodnotovým rebríčkom rodinného prostredia.

Pokial' ide o dospelú populáciu, sociologička Elizabeth Longová už v roku 1986 zaznamenala vo verejných čitatel'ských kurzoch - určených primárne pre ženy pochádzajúce zo strednej triedy - výrazný nárast sebauvedomenia a sebavedomia (Long, 2003).

Ďalšou oblast'ou, v ktorej sa výrazne prejavil potenciál beletrie ako výchovného a vzdelávacieho nástroja, bola penitenciárna starostlivost'. V roku 1997 Roger Jarjoura a Susan Krumholzová počas testovacej fázy projektu, ktorej sa zúčastnilo sedemdesiatdva recidivistov, zistili, že opakovaného trestného činu sa dopustilo len približne $20 \%$ probandov navštevujúcich ich literárny seminár $(18,75 \%)$. Na druhej strane, počet účastníkov z kontrolnej skupiny (nenavštevujúcich seminár), ktorí sa dopustili opakovaného trestného činu dosiahol počas testovacej fázy mieru až $45 \%$. V rokoch 2004 - 2005 vyvrcholila výmena názorov medzi profesorom anglickej literatúry Robertom Waxlerom a sudcom Robertom Kaneom, týkajúca sa možností využitia biblioterapie ako výchovného prostriedku v oblasti penitenciárnej starostlivosti, vytvorením testovacieho projektu s názvom Changing Lives Through Literature (Zmena života

(biblioterapiou) zaoberá najmä B. Valešová Malecová v početných publikáciách: Vývinová biblioterapia u detí predškolského a školského veku (2015), Využitie vývinovej biblioterapie $v$ inkluzivnom procese na základenej škole (2016), Vývinová biblioterapia u detí staršieho školského veku a adolescentov (2016), Práca s príbehom v obdobi predškolského veku I. (2017-2018). 
pomocou literatúry; Trounstine, Waxler, 2005). Napokon sa zhodli, že niektorí trestanci by namiesto nepodmienečného trestu mali dostat' možnost' podmienečného výkonu trestu, ktorého súčast'ou by bolo navštevovanie literárneho seminára o modelových rolách.

Obdobný výchovno-vzdelávací program bol v Chicagu vytvorený pre neplnoleté slobodné matky. Prvého cyklu seminára Literature for all of us (Literatúra pre nás všetkých) sa pod vedením Karen Thomsonovej zúčastnilo 4500 osôb. Zistenia po ukončení výskumu preukázali „výrazný nárast schopností účastníčok projektu v oblasti kritického myslenia a riešenia problémových situácií. Pedagogickí a sociálni pracovníci navyše zaznamenali výrazné zlepšenie ich správania, ktoré prisudzovali zručnostiam osvojeným na stretnutiach čitatel'ských skupín“11 (Oatley, Mar, Djikic, $2009,14)$. Kontrolný prieskum s odstupom času tiež ukázal, že „viac ako 65 \% účastníčok čitatel'ských kurzov začalo vo svojom vol'nom čase viac čítat"'12 (Oatley, Mar, Djikic, 2009, 14).

\section{Záver}

V štúdii sme poukázali na kultúrnoantropologický, respektíve evolučný charakter (v univerzálnej aj individuálnej rovine) fenoménu naratív a ich spätost' so sociálnym životom a komunikáciou v rámci danej kultúrnej komunity.

Nevyhnutným predpokladom na to, aby bolo možné naratíva (príbehy) efektívne používat' v sociálnej a vzdelávacej práci s mládežou i dospelými je ich pútavost' pre čitatel'a alebo poslucháča. V tomto zmysle je podl'a W. Labova (1997) žiaduce, aby naratíva napĺn̆ali dve hlavné kritériá: podávaná informácia musí obsahovat' prvok prekvapenia (musí byt’ v istom zmysle nečakaná) a musí mat' potenciál vyvolat' emocionálnu reakciu príjemcu.

Olsenová (2011) vo svojej dizertácii s názvom Fictional Stories Reveal Human Biases (Fiktívne príbehy odhal'ujú l’udské sklony) pridáva

${ }^{11},[\ldots]$ significant developments in the use of critical thinking and problem-solving skills. School staff also noted improvements in participants' behaviour, which they attributed to the skills learned in book groups".

${ }^{12},[\ldots]$ over $65 \%$ of book group participants reported reading more often on their own after joining book group“. 
k predpokladom (kritériám) čitatel'sky prít’ažlivého naratíva d'alšie dva aspekty: novost' (angl. novelty) a sledovanie, resp. dosiahnutie nejakého ciel'a. Rozprávanie musí podl'a nej implikovat' určitý zámer protagonistu (zmysel jeho konkrétneho konania), ku ktorého realizácii príbeh prirodzene smeruje a stáva sa jeho vyvrcholením.

My pridávame d'alšie štyri kritériá: hodnovernost' (v zmysle pravdepodobnej reálnosti) narácie, spôsob (literárneho) spracovania, selektívnost' a kognitívny prínos pre príjemcu. Prvé kritérium odvodzujeme od sklonu l'udskej psychiky zameriavat' sa prednostne na prakticky využitel'né informácie (v živote) a na informácie či situácie potvrdzujúce našu osobnú skúsenost', naše osobné poznanie. Druhé uvádzané kritérium súvisí predovšetkým s formálnymi aspektmi naratív (literárnym štýlom), pretože aj banálny a nezaujímavý príbeh možno totiž podat' netradičným, humorným, dramatickým či lingvisticky invenčným spôsobom ${ }^{13}$.

Tretie kritérium - selektívnost' (výberovost') - je dôsledkom nášho presvedčenia, že žiadny čitatel' (poslucháč) dobrovol'ne nezotrvá v situácii (čítanie, počúvanie príbehu), ktorá nezodpovedá jeho svetonázoru a osobným preferenciám. V praxi to znamená, že nie je pravdepodobné, aby presvedčený veriaci čítal príbehy o čarodejníkovi Harrym Potterovi ${ }^{14}$, aby pacifista sledoval akčné filmy, alebo, aby si vegetarián listoval v kuchárskej knihe venovanej mäsitým jedlám (recept ako narácia).

Posledné, nami navrhované kritérium, osobný (kognitívny) prínos, sa sčasti prelína s predchádzajúcou kategóriou, pretože ako čitatelia - vedome či podvedome - vždy siahame po knihe, o ktorej predpokladáme, že uspokojí (aspoň do istej miery) naše dlhodobé (zodpovedajúce našim záujmom a nášmu svetonázoru) či aktuálne potreby (napr. pocity l’útosti, zlyhania, viny či zúfalstva spôsobené aktuálnou krízou v milostnom vzt’ahu). Kritérium kognitívneho prínosu chápeme skôr v zmysle rozšírenia (osobnej „databázy“) poznatkov a „osobnej múdrosti“ o takú informáciu (zistenie), ktorá je pre náš d’alší život významná (z osobnostného, profesionálneho, interpersonálneho hl'adiska a pod.). V tejto súvislosti možno kritérium kognitívneho prínosu doplnit'

\footnotetext{
${ }^{13}$ Istým spôsobom ide o kombináciu kritérií novosti a prekvapenia, avšak aplikovaných na formálnu stránku naratíva.

${ }^{14} \mathrm{Z}$ pohl'adu krest’anstva predstavuje mágia - „čarovanie“ zakázanú formu kontaktu s duchovným svetom, pretože jeho ciel'om býva obyčajne ovplyvňovanie myslenia a konania iných osôb, t. j. zbavovanie človeka slobodnej vôle.
} 
aj o kategóriu emocionálneho prínosu chápaného ako zážitok celkom novej emócie alebo „zopakovanie“ dlhodobo individuálne preferovanej emócie či citového zážitku celkovo prispievajúceho k nášmu osobnostnému rastu (napr. mystická skúsenost', zážitok obety a pod.) $)^{15}$.

\section{Literatúra}

Bangerter, A. (2000). Transformation between Scientific and Social Representations of Conception: the Method of Serial Reproduction. „British Journal of Social Psychology" no. 39, s. 521-535.

Bartlett, F. C. (1932). Remembering: A Study in Experimental and Social Psychology. Cambridge: Cambridge University Press.

Bátoryová, D., Kusý, P. (2012). Využitie muzikoterapie pri práci s det’mi. In: Evropské pedagogické fórum 2012. Hradec Králové: Magnanimitas, s. 261-267.

Boyd, B. (2009). On the Origin of Stories: Evolution, Cognition and Fiction. Cambridge, MA: Harward University Press.

Bílek, P. (2003). Hledání jazyka interpretace. K modernímu prozaickému textu. Brno: Host.

Brewer, W. F., Nakamura, G. V. (1984). The Nature and Funcions of Schemas. In: Handbook of Social Cognition. Eds R. S. Wyer, T. K. Srull, Hillsdale, New York: Erlbaum, s. 119-160.

Brewer, W. F. (1985). The Story Schema: Universal and Culture-specific Properties. In: Literacy, Language, and Learning. Eds D. R. Olson, N. Torrance, A. Hildyard, Cambridge: Cambridge University Press, s. 167-194.

Chaffe, W. (1990). Some Things That Narratives Tell Us about the Mind. In: Narrative Thought and Narrative Language. Eds B. K. Britton, A. D. Pellegrini, Hillsdale: Lawrence Erlbaum Associates, Inc.

Cingerová, N., Dulebová, I. (2019). Jazyk a konflikt. My a tí druhí v ruskom verejnom diskurze. Bratislava: Univerzita Komenského.

Cook, G. (1997). Language Play, Language Learning. „ELT Journal“ 51/3, s. 224-231.

Dessalles, J.-L. (2007). Why We Talk - The Evolutionary Origins of Language. Oxford: Oxford University Press.

Dessalles, J.-L. (2008). Spontaneous Narrative Behaviour in Homo Sapiens: How Does It Benefit to Speakers? In: The Evolution of Language: Proceedings of the $7^{\text {th }}$ International Conference (EVOLANG7). Eds A. D. M. Smith, K. Smith, R. F. Cancho. World Scientific Publishing, s. 91-98.

Eeggins, S., Slade, D. (1997). Analysing Casual Conversation. London: Equinox. Fülöpová, M. (2014). Odvrávajúce obrazy. Bratislava: Univerzita Komenského.

${ }^{15} \mathrm{~V}$ tejto súvislosti vnímame ako vel'mi podnetné napr. Grittiho štúdie o duchovnom hl'adaní (Gritti, 2014) a zmysle l'udského utrpenia (Gritti, 2015). 
Fülöpová, M. (2020). Archetypálny hrdina v idylickom svete. In: SAS 49. Eds M. Vojtech, J. Pekarovičová. Bratislava: Univerzita Komenského.

Gallese, V., Wojsciehowski, H. (2010). How Stories Make Us Feel: Toward an Embodied Narratology. „California Italian Studies“ 2/1, s. 1-19.

Gerring, R. J. (1989). Reexperiencing Fitcion and Non-fiction. „Journal of Aesthetics and Art Criticism“ 47/3, s. 277-280.

Gottschall, J. (2008). Literature, Science, and New Humanities. New York: Palgrave Macmillian.

Gritti, F. (2014). Duchovné hl'adanie v hermetickej poézii Mária Luziho. „World Literature Studies" 6/1, s. 21-32.

Gritti, F. (2015). Zmysel l’udského utrpenia v poézii Mária Luziho. In: Duchovná cesta a jej podoby v literatúre. Ed. M. Kučerková. Nitra: UKF.

Halász, L. (1991). Effect and Reminding in Literary Text Processing. In: Empirical Studies of Literature. Eds E. I. D. Schram, G. Steen. Amsterdam: Rodopi, s. 79-85.

Hogan, P. C. (2003). The Mind and Its Stories. Narrative Universals and Human Emotions. Cambridge: Cambridge University Press.

Hsu, J. (2008). The Secrets of Storytelling. „Scientific American Mind“ 19, s. 46-51.

Jarjoura, G. R., Krumholz, S. T. (1998). Combining Bibliotherapy and Positive Role Modeling as an Alternative to Incarceration. „Journal of Offender Rehabilitation“ 28, s. 127-139.

Keen, S. (2006). A Theory of Narrative Empathy. „Narrative“ 14, s. 207-236.

Kusý, P. (2015). Interpersonálna teória hudby a hudobná mediácia u detí. In: Dimenzia muzikoterapie v praxi, výskume a edukácii. Eds P. Krajčí, K. Priesterová. Bratislava: IRIS, s. 166-172.

Kusý, P. (2018). Interpersonálna teória hudby: teoretické východiská, výskumné rezultáty a možnosti aplikácie. Trnava: Typi Universitas Tyrnaviensis.

Labov, W. (1997). Some Further Steps in Narrative Analysis. „Journal of Narrative and Life History" vol. 7/1-4, s. 395-415.

Long, E. (2003). Book Clubs: Women and the Uses of Reading in Everyday Life. Chicago, IL: University of Chicago Press.

Lyons, A., Kashima, Y. (2003). How Are Stereotypes Maintained through Communication? „Journal of Personality and Social Psychology“ 85, s. 989-1005.

Mar, R. A., Oatley, K. (2008). The Function of Fiction in the Abstraction and Simulation of Social Experience. „Perspectives on Psychological Science“ 3/3, s. 173-192.

Mar, R. A. et al. (2006). Bookworms vs. Nerds: Exposition to Fiction vs. Non-fiction, Divergent Associations with Social Ability, and the Simulation of Fictional Social Worlds. „Journal of Research in Personality“ 40, s. 694-712.

Mehl, M. R.,Vazire, S., Ramírez-Esparza, N., Slatcher, R. B., Pennbaker, J. W. (2007). Are Women Really More Talkative than Men? „Science“ 317/5837, s. 82.

Mesárová, E. (2014). Fantastika a jej uplatnenie v talianskej postmodernej próze. „Jazyk a literatúra" $1 / 1$, s. 26-45.

Mesárová, E. (2015). Il fenomeno del realismo magico e del fantastico nella letteratura italiana. In: Quo vadis, Romanistica? 5. Bratislava: UK, s. 47-56. 
Mesoudi, A., Whiten, A. (2008). The Multiple Roles of Cultural Transmission Experiments in Understanding Human Cultural Evolution. „Philosophical Transactions of the Royal Society B“363, s. 3489-3510.

Oatley, K., Mar, R. A. (2005). Evolutionary Pre-adaptation and the Idea of Character in Fiction. „Culture and Evolutionary Psychology“ 3, s. 181-196.

Olsen, A. (2011). Fictional Stories Reveal Human Biases: How a Preference for Tales of Resourceful Heroes Sheds Light on the Evolution of Language. Edinburgh: University of Edinburgh.

Paris, B. J. (1997). Imagined Human Beings: a psychological Approach to Caracter and Conflict in Literature. New York-London: New York University Press.

Plichtová, J. (2002). Metódy sociálnej psychológie zblizka. Kvalitatívne a kvantitatívne skúmanie sociálnych reprezentácií. Bratislava: Média.

Prince, G. (1987). A Dictionary of Narratology. Lincoln: University of Nebraska Press.

Remjanová, K., Valešová Malecová, B. (2017-2018). Práca s príbehom v obdobi predškolského veku (1). „Predškolská výchova“ roč. 72, č. 2, s. 21-25.

Sarbin, T. R. (1986). The Narrative as a Root Metaphore for Psychology. In: Narrative Psychology. The Storied Nature of Human Conduct. Ed. T. R. Sarbin. New York: Praeger Publishers, s. 3-21.

Sscholes, R., Kellogg, R. (1966). The Nature of Narrative. New York: Oxford University Press.

Skulsky, H. (1980). On Being Moved by Fiction. „Journal of Aesthetics and Art Criticism“ 39/1, 5-14.

Štubňa, P. (2017). Psychológia literatúry. 2. vydanie. Bratislava: Univerzita Komenského.

Tabačková, K., Kusý, P. (2014). Rozvíjanie hudobnej tvorivosti u detí. „Naša škola“ 17/5-6, s. 16-22.

Todorov, T. (2002 [1966]). Kategorie literárního vyprávění. In: Znak, struktura, vyprávěni. Výbor z praci francouzského strukturalismu. Ed. P. Kyloušek. Brno: Host.

Trounstine, J. R., Waxler, R. P. (2005). Finding a Voice: the Practise of Changing Lives through Literature. Ann Arbor, MI: University of Michigan Press.

Valešová Malecová, B. (2015). Vývinová biblioterapia u detí predškolského a školského veku. In: Špeciálnopedagogické poradenstvo, Informačný bulletin XIX. Bratislava: Výskumný ústav detskej psychológie a patopsychológie, s. 25-36.

Valešová Malecová, B. (2016). Využitie vývinovej biblioterapie v inkluzívnom procese na základnej škole. In: Expresivita v (art)terapii. Bratislava: Univerzita Komenského, s. 32-40.

Valešová Malecová, B. (2016). Vývinová biblioterapia u deti staršieho školského veku a adolescentov. In: Expresívne terapie vo vedách o človeku. Bratislava: Univerzita Komenského, s. 16-25.

Walton, K. L. (1978). Fearing Fictions. „Journal of Philosophy“ 75/1, s. 5-27.

Zunshine, L. (2006). Why we Read Fiction: Theory of Mind and the Novel. Columbus, Ohio: State University Press. 